\title{
Biological and morphological traits of sugarcane roots in relation to phosphorus uptake
}

\author{
Bruna Arruda ${ }^{1}$ Marcos Rodrigues $^{1}$, Amin Soltangheisi ${ }^{1}$, Alan E. Richardson ${ }^{2}$, Fernando Dini \\ Andreote $^{1}$, Paulo Sergio Pavinato ${ }^{1 *}$ \\ ${ }^{1}$ Department of Soil Science, University of Sao Paulo, College of Agriculture "Luiz De Queiroz" - USP/ES- \\ ALQ.Av. Pádua Dias, 11. CEP 13418-900. Piracicaba-SP, Brazil.*Corresponding author: pavinato@usp.br \\ ${ }^{2}$ CSIRO, Agriculture, PO Box 1600, Canberra, ACT, 2601, Australia.
}

\begin{abstract}
Appropriate management of phosphorus $(\mathrm{P})$ in soil will lead to higher yields and sustainability for sugarcane production. Our study evaluated the importance of differences in root structure and function, and the differential composition of the bacterial community in four sugarcane cultivars, in relation to the efficiency for P uptake and also to assess changes in soil $\mathrm{P}$ with distance from the rhizoplane. Experiments were performed in pot trials using a sandy clay loam Ferralsol. In the first experiment, the effect of P application (78.4 $\mathrm{mg} \mathrm{P} \mathrm{kg}^{-1}$ soil astriple superphosphate) on sugarcane cultivars RB92-579; RB85-5156; RB86-7515 and RB96-6928 was investigated. Secondly, we evaluated $P$ rates of 0; 9.8; 19.6; 39.2 and $78.4 \mathrm{mg} \mathrm{kg}^{-1}$ soil using cultivar RB96-6928 which was shown to be one of the more growth responsive cultivars. The cultivar RB96-6928 exhibited the highest root dry matter and root surface area, while the bacterial communities found in the rhizosphere of these plants were not different from other cultivars, as determined by PCR-DGGE. From the P dose-dependent experiment for this cultivar, optimal plant performance occurred at a P supply up to $38.5 \mathrm{mg} \mathrm{P} \mathrm{kg}^{-1}$ soil. Collectively, our results indicate that $\mathrm{P}$ efficiency in sugarcane was predominantly associated with the generation of high root biomass and surface area.
\end{abstract}

Keywords: P efficiency, Phosphate, Rhizosphere, Root morphology, Saccharum spp.

\section{Introduction}

Management of phosphorus (P) is a key challenge for sustainable sugarcane production in Brazil, the country that hold the largest sugarcane production in the world (FAO, 2013; CONAB, 2015). In tropical soils, fertilization requires excessive amounts of $\mathrm{P}$ to be applied in order to overcome high rates of $\mathrm{P}$ adsorption (clay, $\mathrm{Fe}$ and $\mathrm{Al}$ oxides) or precipitation ( $\mathrm{Fe}$ or $\mathrm{Al}$ in soil solution)in soil (Khan et al., 2010).The estimated 
efficiency for P uptake by plants from applied P fertilizer in the year of application is about $20 \%$ in tropical soils (Raghothama and Karthikeyan, 2005).

$\mathrm{P}$ uptake by roots is controlled by many factors including spatial variability, bioavailability of soil $\mathrm{P}$ and acquisition efficiency (Shen et al., 2011). The main mechanism of the movement of $\mathrm{P}$ from soil to roots is diffusion. However, the mobility of $\mathrm{P}$ is very low in soil and hence root growth and morphology, interception and contact between roots and soil are key features that influence plant nutrition. Symbiosis between roots and arbuscular mycorrhizal fungi (AMF) (Machado and Furlani, 2004) may also allow greater exploration of soils through increased absorptive surface in the root system (Larsen et al., 2015). Interaction with free-living microorganisms is also important through plant exudation of carbon to recruit microbes that potentially are able to either solubilize or mineralize inorganic and organic forms of $\mathrm{P}$ in soil (Richardson and Simpson, 2011).

Different cultivars of sugarcane are used in sugar plantations as an agronomic tool to alter plant development, harvest season, pests and diseases resistance, nutrient supply and to obtain maximum yields. The Ridesa varieties (RB) developed by a network of ten Brazilian federal universities, presently account for $69 \%$ of the cultivated area for sugarcane in the crop season 2014/15. According to a data compilation by Sugarcane Breeding Program (PMGCA), cultivars RB92-579, RB86-5156, and RB86-7515 are the most high-yielding in Brazil. Cultivar RB92-579, is tolerant to drought and also responsive to irrigation, has high tillering per plant and is reported to show high nutrient use efficiency. RB86-5156 is an early maturing cultivar with high yield stability. RB86-7515 has high cane yield and is considered to be adapted to poor soil fertility conditions. Another cultivar released recently, RB96-6928, is a cultivar that has an earlier growth cycle with good ratoon development and is favorable for mechanic harvesting.
Whilst these cultivars are widely used throughout Brazil and appear to be adapted to a wide range of soil conditions, systematic assessment of their capacity for differential extraction of $\mathrm{P}$ from soil has not been investigated. We hypothesized that differences in genetic backgrounds of these cultivars would enable plants to utilize different strategies to acquire $\mathrm{P}$ from soil through variation in root system structure and associated rhizosphere processes (Pinton et al., 2001). In this paper we investigate morphological changes in root structure and rhizosphere properties in the four sugarcane cultivars listed above in relation to sugarcane $\mathrm{P}$ uptake and growth response. The cultivars were evaluated according to the efficiency of root systems for $\mathrm{P}$ uptake and associated changes in properties of rhizosphere soil at different distances from the root surface. The objective of the work is to identify P-efficient cultivars of sugarcane that may reduce $P$ fertilizer application and thus improve environmental sustainability of sugar production.

\section{Material and Methods}

\subsection{Soil characterization}

Two experiments were run in pot trials using a soil collected from the $0-20 \mathrm{~cm}$ layer of a grassland located at Piracicaba-SP, Brazil (coordinates $-47^{\circ} 38^{\prime}$ 57E,-22 ${ }^{\circ}$ $\left.43^{\prime} 31 \mathrm{~S}\right)$. The soil analysis was performed showing: clay content $=201 \mathrm{~g} \mathrm{~kg}^{-1}$; organic matter $=2.2 \% ; \mathrm{pH}_{\mathrm{Ca}}$ $\mathrm{Cl}_{2}(1: 1)=4.3 ; \mathrm{Ca}=8 \mathrm{mmol}_{\mathrm{c}} \mathrm{kg}^{-1} ; \mathrm{Mg}=5 \mathrm{mmol}_{\mathrm{c}} \mathrm{kg}^{-1} ; \mathrm{P}$ extracted by anion exchange resin $\left(\mathrm{P}_{\mathrm{AER}}\right)=5.4 \mathrm{mg} \mathrm{kg}^{-1}$; $\mathrm{K}=1.4 \mathrm{mmol}_{\mathrm{c}} \mathrm{kg}^{-1}$; cation exchange capacity $(\mathrm{CEC})=$ $45 \mathrm{mmol}_{\mathrm{c}} \mathrm{kg}^{-1}$; base saturation $(\mathrm{V})=31.7 \%$. The soil is classified as a sandy clay loam Ferralsol, with low availability of nutrients $\left(\mathrm{Ca}, \mathrm{Mg}, \mathrm{K}\right.$ and $\left.\mathrm{P}_{\mathrm{AER}}\right)$. Prior to experiments, the soil was air-dried and sieved on 2 $\mathrm{mm}$ mesh, remoistened with deionized water to $80 \%$ of the field capacity and incubated for 15 days with 
lime (2.5 $\mathrm{g} \mathrm{kg}^{-1}$ soil) to achieve a base saturation of $70 \%$ (Raij et al., 1997). Soil was supplemented with potassium and nitrogen using $\mathrm{KCl}\left(50 \mathrm{mg} \mathrm{K} \mathrm{kg}^{-1}\right.$ soil) and urea (30 $\mathrm{mg} \mathrm{N} \mathrm{kg}^{-1}$ soil), respectively. Two additional inputs of nitrogen were made during plant growth (both at rate of $15 \mathrm{mg} \mathrm{N} \mathrm{kg}^{-1}$ soil), at 15 and 30 days after seedling transplantation.

Both experiments were conducted in a greenhouse (mean $20-25^{\circ} \mathrm{C}$ ), using a randomized block design with four replications.

\subsection{Sugarcane cultivars growth, plant harvest and analysis of root and rhizosphere}

The first experiment was run with four sugarcane cultivars currently used in Brazil (RB92-579; RB855156; RB86-7515 and RB96-6928) with distinct genetic background and morphological/physiological features. Seedlings were germinated in sterile vermiculite for 22 days for standardizing the initial development. Those seedlings were transplanted into polyvinyl chloride (PVC) tubes $(0.15 \mathrm{~m}$ diameter and $0.45 \mathrm{~m}$ tall) packed with soil at a density of $\sim 1.2 \mathrm{~kg}$ $\mathrm{dm}^{-3}$ ( similar to the density in the field). One plant was grown per pot during for 45 days.

Plants were grown under low (NP), without $\mathrm{P}$ application, and high $\mathrm{P}$ levels (WP) using fertilizer application at rate of $78.4 \mathrm{mg}$ soluble $\mathrm{P} \mathrm{kg}^{-1}$ soil $(\sim 180 \mathrm{mg}$ $\mathrm{P}_{2} \mathrm{O}_{5} \mathrm{~kg}^{-1}$ soil) based on soluble $\mathrm{P}$, from the fertilizer, provided as triple superphosphate (TSP, 45\% soluble $\mathrm{P}_{2} \mathrm{O}_{5}$ ) applied per pot and homogenized in the volume of the soil. After the soil P application it is estimated that the final available P should be around $22.4 \mathrm{mg}$ $\mathrm{kg}^{-1}$.

At harvest (45 days after transplant) number of tillers was counted for each pot. Plants and soil were then carefully removed from the PVC tube and used for shoots, roots, rhizosphere, and soil analyses. Shoots were excised at soil surface, dried in an oven at $60^{\circ} \mathrm{C}$ until constant mass, weighed, milled and passed through a $1 \mathrm{~mm}$ sieve. The P content in the shoot was determined by the vanadate-yellow colorimetric method (Malavolta et al., 1997).

The root systems were carefully divided, i $\mathrm{n}$ a vertical section, into two equal parts based, on pot volume with a proportional representation. The first half of each sample was collected by rinsing on a $2 \mathrm{~mm}$ mesh and was subsequently stored in $70 \%$ ethanol. Roots were then scanned using a flatbed scanner EPSON Expression 10000XL at 600 dots per inch (dpi). WinRhizo Pro 2009c (Regent Instruments Inc.) software was used to analyze the scanned images to determinate root morphological characters, including total root length, mean root diameter, root surface area and total root volume. Root samples were then dried at 60 ${ }^{\circ} \mathrm{C}$ to estimate proportionally the total root dry mass (estimated from $50 \%$ of the pot to the entire pot). The second half of each root sample was similarly washed and then assessed for extent of mycorrhizal colonization (MC) and determination of $\mathrm{P}$ contents in root tissue. $\mathrm{MC}$ analysis was conducted by immersion of roots in $\mathrm{KOH}$ and staining with ink blue (Giovannetti and Mosse, 1980). After that, roots were dispersed in Petri dishes and observed using a stereomicroscope for the presence of typical structures of AMF, which were quantitatively scored based on observation frequency (Vierheilig et al., 1998). The content of $\mathrm{P}$ in roots was determined as described for analysis of shoots.

Soil adhered to the root system (remaining after hand agitation) was considered as rhizosphere soil. This soil was used for analysis of acid phosphatase activity $\left(\mathrm{AP}_{\mathrm{ASE}}\right)$ (Tabatabai, 1994), phosphorus in the microbial biomass $\left(\mathrm{P}_{\text {MIC }}\right)$ (Brookes et al., 1985, Vance et al., 1987) and determination of bacterial community structure based on PCR-DGGE (Heuer et al., 1997). Total DNA was extracted using the PowerSoil DNA isolation kit (MoBio, Carlsbad, EUA) according to 
the manufacturer instructions and PCR and DGGE of partial 16S-rDNA genes was performed as outlined by (Heuer et al., 1997). After, the soil was dried $\left(60^{\circ} \mathrm{C}\right)$ and $\mathrm{P}$ extracted by anion exchange resin $\left(\mathrm{P}_{\mathrm{AER}}\right)$ was determined using $2 \mathrm{~cm}^{2}$ resin strips saturated with $\mathrm{NaHCO}_{3}\left(0.5 \mathrm{~mol} \mathrm{~L}^{-1}\right)$, and further immersed in $10 \mathrm{ml}$ of $\mathrm{H}_{2} \mathrm{O}$, subjected to 16 hours agitation in an orbital shaker. Inorganic $\mathrm{P}$ in the acid extract was quantified by colorimetric assay using the molybdate blue method (Murphy and Riley 1962).

In all cases, data from rhizosphere were compared to bulk soil, represented by samples collected in control pot without plant cultivation.

\subsection{Sugarcane growth and rhizosphere P response in different distances from the rhizoplane}

The second experiment was run with the cultivar RB96-6928 (selected from the first experiment) in the same Ferralsol soil, with five levels of $\mathrm{P}$ as TSP fertilizer ( $45 \%$ soluble $\mathrm{P}_{2} \mathrm{O}_{5}$ ), based on soluble P:0, 9.8, 19.6, 39.2 and $78.4 \mathrm{mg} \mathrm{kg}^{-1}$ (estimated to be applied more $0 ; 2.25 ; 4.5 ; 9.0$ and $18.0 \mathrm{mg}$ of available $\mathrm{P}$ $\mathrm{kg}^{-1}$ soil, respectively). Plant growth conditions, shoot sampling and processing were similar to procedures described above. For rhizosphere analysis, a more detailed approach was used, whereby a nylon mesh $(25$ microns) was inserted to separate the rhizoplane from rhizosphere soil (Gahoonia and Nielsen, 1991). PVC columns were modified to allow a lower column ( 0.05 $\mathrm{m})$ to be attached to the upper one $(0.15 \mathrm{~m})$ with subsequent sampling of rhizosphere soil at distances of 1 (0-2); 3 (2-4); 5 (4-6); 7 (6-8) and 9 (8-10) $\mathrm{mm}$ from the rhizoplane-nylon mesh interface. Soil sections were sampled using a screw-based plate mechanism which allowed the soil to be raised and shaved according to rhizosphere distances.

Soil $\mathrm{pH}$ was determined (0.01 $\left.\mathrm{M} \mathrm{CaCl}_{2} 1: 5 \mathrm{w}: \mathrm{v}\right)$ in all samples as an indicator of the rhizosphere dis- tance and samples were similarly analyzed for $\mathrm{P}_{\mathrm{MIC}}$ and $\mathrm{AP}_{\mathrm{ASE}}$ as described above. The $\mathrm{P}$ composition of each soil fraction was analyzed by sequential extraction using representative $0.5 \mathrm{~g}$ subsamples of dried and sieved soil. Labile soil $\mathrm{P}$ was extracted by anion exchange resin $\left(\mathrm{P}_{\mathrm{AER}}\right)$ as described above.

\subsection{Statistical analysis}

The comparison among sugarcane cultivars was made by two-way (cultivar $\mathrm{x} P$ application) analysis of variance (ANOVA) and significance $(p=0.05)$ determined by $\mathrm{F}$ values. When significant $\mathrm{F}$ value was detected, comparison of means was performed using the Duncan multiple range test. When the interaction cultivar $\mathrm{x}$ P application was significant, cultivars were compared across each P level.

DGGE gel profiles were photo documented with Storm 845 (General Electric) and analyzed using the ImageQuant TL unidimensional (Amersham Biosciences, Amersham, UK, v. 2003) (McCaig et al., 2001), where band patterns were converted in matrices of presence/absence of bands. The Past Statistics 1.90 program (Hammer et al., 2001) was used and data analyzed by PERMANOVA and principal coordinate analysis (PCA) based in the Bray-Curtis algorithm.

For modulation of sugarcane response to differing $\mathrm{P}$ levels, the data were subjected to one-way ANOVA ( $\mathrm{P}$ rate) and data with significant effect $(p=0.05)$ were subjected to adjustment of the most significant regression.

\section{Results}

\subsection{Analysis of root systems in response to $P$ application}

Root systems were influenced markedly by P application, whereby total root length, average root diameter and total volume of root were significantly increased $(p \leq 0.05)$ 
across all 4 cultivars with P application (Table 1). Root mass fraction (proportion of root mass compared to total plant mass) was significantly decreased ( 2-fold across all cultivars) by $\mathrm{P}$ application. Variation in response was also observed across cultivars. Regardless of the P appli- cation, cultivar RB96-6928 showed the highest total root length and diameter and as consequently had greater $(p<$ 0.05 ) root volume at both NP and WP. Cultivar RB966928 also showed the highest root mass fraction both with and without $\mathrm{P}$ application.

Table 1. Total root length, mean root diameter, total volume of root system and root mass fraction for four cultivars grown without $\mathrm{P}$ application (NP) and with $\mathrm{P}(\mathrm{WP})$ supplied.

\begin{tabular}{|c|c|c|c|c|c|c|c|c|c|c|c|c|}
\hline \multirow[t]{2}{*}{ Cultivar } & \multicolumn{3}{|c|}{ Total root length } & \multicolumn{3}{|c|}{ Mean root diameter } & \multicolumn{3}{|c|}{ Total volume of root system } & \multicolumn{3}{|c|}{$\begin{array}{l}\text { Root mass fraction }{ }^{\dagger} \\
----\% \text { root mass---- }\end{array}$} \\
\hline & $\mathrm{NP}$ & WP & Mean & NP & WP & Mean & NP & WP & Mean & NP & WP & Mean \\
\hline RB92-579 & $10282^{n}$ & nis 34468 & $22375 \mathrm{AB}$ & 2.09 & 3.72 & $2.90 \mathrm{AB}$ & 15.6 & 38.8 & $27.2 \mathrm{~B}$ & 29.0 & 16.4 & $22.7 \mathrm{AB}$ \\
\hline RB85-5156 & 10539 & 27795 & $19167 \mathrm{AB}$ & 1.94 & 3.79 & $2.87 \mathrm{AB}$ & 16.7 & 43.0 & $29.8 \mathrm{AB}$ & 29.8 & 14.3 & $21.0 \mathrm{~B}$ \\
\hline RB86-7515 & 12686 & 17669 & $15178 \mathrm{~B}$ & 2.25 & 3.02 & 2.63 & 18.8 & 30.9 & $24.9 \mathrm{~B}$ & 28.9 & 13.9 & $21.4 \mathrm{~B}$ \\
\hline RB96-6928 & 19144 & 30371 & $24757 \mathrm{~A}$ & 3.55 & 5.23 & $4.39 \mathrm{~A}$ & 35.3 & 55.9 & $45.6 \mathrm{~A}$ & 35.0 & 21.0 & $28.0 \mathrm{~A}$ \\
\hline Mean & $13163 \mathrm{~b}$ & b 27576 & & 2.46 & 3.94 & & 21.6 & 42.2 & & 30.8 & $16.4 \mathrm{~b}$ & \\
\hline
\end{tabular}

Different capital letters within the same column show significant differences between cultivars by LSD test ( $p \leq 0.05)$. Different small letters within the same row show significant difference between NP and WP by LSD test $(p \leq 0.05)$. ${ }^{\text {ns }}$ Not significant by LSD test $(\mathrm{p}>0.05)$

$\dagger$ Root mass fraction $=\mathrm{DM}($ root $) / \mathrm{DM}($ shoot + root $)$.

Mycorrhizal colonization (MC) showed interaction between $\mathrm{P}$ application and cultivars $(p \leq 0.05)$. Under WP there was no difference between cultivars. Under NP the cultivar RB86-7515 showed the lowest MC, being similar to the other cultivars under high $\mathrm{P}$ (WP). Cultivars RB92-579, RB85-5156 and RB96-6928 all had higher colonization under NP compared to WP (Table 2).

Table2. Mycorrhizal colonization (MC) for four cultivars grown without P application (NP) and with P(WP) supplied.

\begin{tabular}{|c|c|c|c|}
\hline \multirow{3}{*}{ Cultivar } & \multicolumn{3}{|c|}{ Mycorrhizal colonization } \\
\hline & \multicolumn{3}{|c|}{ - } \\
\hline & NP & WP & Mean \\
\hline RB92-579 & $41 \mathrm{Aa}$ & $24 \mathrm{Ab}$ & 33 \\
\hline RB85-5156 & $41 \mathrm{Aa}$ & $24 \mathrm{Ab}$ & 33 \\
\hline RB86-7515 & $29 \mathrm{Ba}$ & $26 \mathrm{Aa}$ & 27 \\
\hline RB96-6928 & $35 \mathrm{ABa}$ & $25 \mathrm{Ab}$ & 30 \\
\hline Mean & 36 & 25 & \\
\hline
\end{tabular}

Different capital letters within the same column show significant differences between cultivars by LSD test ( $p \leq 0.05)$. Different small letters within the same row show significant difference between NP and WP by LSD test $(p \leq 0.05)$. ${ }^{\mathrm{ns}}$ Not significant by LSD test $(p>0.05)$. 


\subsection{Phosphorus availability and bacterial communities in rhizosphere}

The availability of inorganic $\mathrm{P}$ in rhizosphere soil and from bulk soil extracted by anion exchange resin $\left(\mathrm{P}_{\mathrm{AER}}\right)$ is shown in Table 3. Large difference $(p<0.05)$ was observed in the labile $\mathrm{P}$ fraction in response to $\mathrm{P}$ fertilization, without no significant effect of sugarcane cultivar (at either NP or WP), and with no difference between soils from the four cultivars as compared to the no plant control (Table 3).

Table 3. $\mathrm{P}$ extracted by anion exchange resin $\left(\mathrm{P}_{\mathrm{AER}}\right)$ and acid phosphatase activity $\left(\mathrm{AP}_{\mathrm{ASE}}\right)$ for four cultivars grown without $\mathrm{P}$ application (NP) and with $\mathrm{P}$ (WP) supplied.

\begin{tabular}{|c|c|c|c|c|c|c|c|}
\hline \multirow[t]{2}{*}{ Cultivar } & \multicolumn{3}{|c|}{$\begin{array}{c}\text { PAER }^{\circ} \\
\mathrm{mg} \mathrm{kg}^{-1}\end{array}$} & \multicolumn{4}{|c|}{$\begin{array}{c}\text { APASE } \\
\mathrm{mg} \mathrm{kg}^{-1} \mathrm{~h}^{-1}\end{array}$} \\
\hline & NP & WP & Mean & NP & WP & & Mean \\
\hline No plant & $2.2^{118}$ & 17.6 & 9.9 ns & $220 \mathrm{Aa}$ & 218 & $\mathrm{Ba}$ & 217 \\
\hline RB92-579 & 2.9 & 16.6 & 9.2 & $170 \quad \mathrm{Ab}$ & 281 & $\mathrm{Aa}$ & 227 \\
\hline RB85-5156 & 2.3 & 16.5 & 9.4 & 217 & 284 & $\mathrm{Aa}$ & 250 \\
\hline RB86-7515 & 1.7 & 15.5 & 8.6 & 179 & 274 & $\mathrm{Aa}$ & 227 \\
\hline RB96-6928 & 2.2 & 16.7 & 9.5 & 188 & 245 & $\mathrm{ABa}$ & 221 \\
\hline Mean & $2.1 \quad b$ & 16.6 & & 195 & 260 & & \\
\hline
\end{tabular}

Different capital letters within the same column show significant differences between cultivars by LSD test ( $p \leq 0.05)$. Different small letters within the same row show significant difference between NP and WP by LSD test $(p \leq 0.05)$. ${ }^{\text {ns }}$ Not significant by LSD test $(p>0.05)$.

$* \mathrm{P}_{\mathrm{AER}}: \mathrm{P}$ extracted by anion exchange resin (Hedley et al. 1982).

The activity of the acid phosphatase $\left(\mathrm{AP}_{\mathrm{ASE}}\right)$ was also influenced by $\mathrm{P}$ availability with cultivars interaction $(p<0.05)$ (Table 3$)$. At low P (NP) there was no difference between cultivars in soil $\mathrm{AP}_{\mathrm{ASE}}$ and the measured activity did not differ to the unplanted control soil. By contrast, under high P (WP), all four cultivars differed from the unplanted control, with exception of cultivar RB96-6928.

Bacterial communities in the rhizosphere and bulk soil were assessed by PCR-DGGE of amplified 16S-rRNA genes. Comparison of bacterial communities showed a clear distinction between treat- ments that was either amended or not with fertilizer P (Figure 1), indicating a significant $(p \leq 0.05)$ plant interaction with soil communities as influenced by $\mathrm{P}$ availability. However, there was no significant difference $(p>0.05)$ in communities across sugarcane cultivars, neither bulk soil nor rhizosphere. In relation to the number of species, calculated by Chao 1 index, also did not show any difference $(p>0.05)$ between cultivars (Data not shown). However the richness was affected $(p \leq 0.05)$ by $\mathrm{P}$ availability, where NP showed 18.4 and WP 11.9 (Data not shown). 


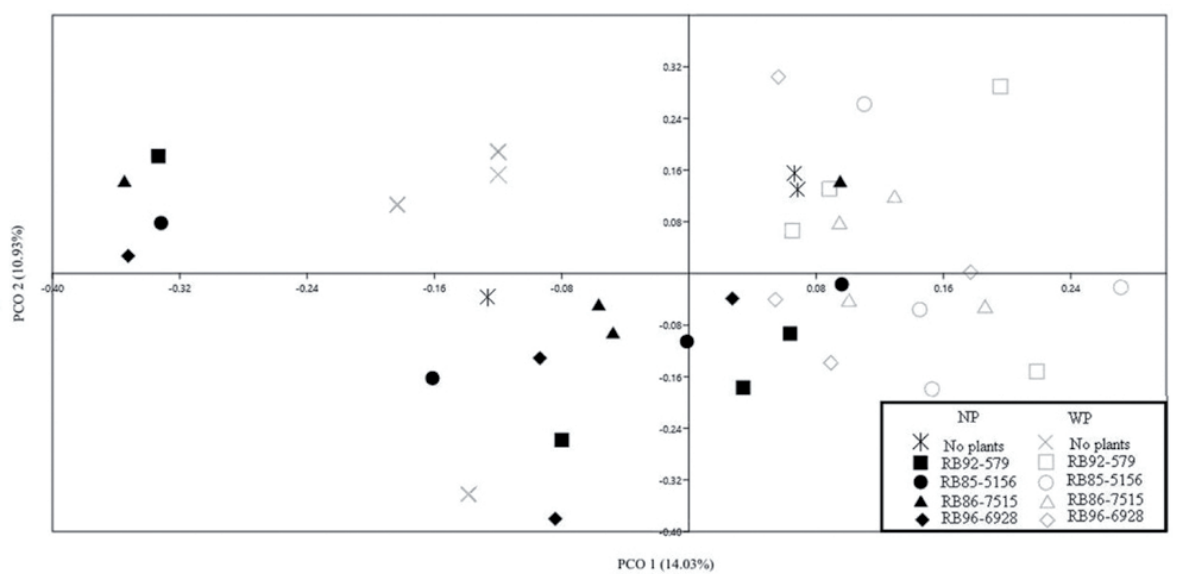

Figure 1. Principal coordinate analyses (PCA) of microbial communities based on DGGE of bacterial 16S-rDNA obtained from rhizosphere soil from four sugarcane cultivars; RB92-579, RB85-5156, RB86-7515 and RB966928 and a bulk soil control with no P application (NP) and with P application (WP).

3.3. Growth response of sugarcane cultivars at low and high $P$ related to the root systems

Growth of the four sugarcane cultivars was significantly affected $(p \leq 0.05)$ by $\mathrm{P}$ application with differences in responsiveness being evident across cultivars. The number of tillers per plant showed strong interaction between $\mathrm{P}$ application and cultivar, with cultivar RB96-6928 having the highest tillers per plant (3.75) at NP, and the other three cultivars producing no or less than one tiller per plant (Table 4). All cultivars produced significantly $(p \leq 0.05)$ more tiller under $\mathrm{P}$ application, with the exception of cultivar RB96-6928 which had the same number of tillers both in low (NP) and high P (WP).

Table 4. Number of tillers per plant for four cultivars of sugarcane grown without $\mathrm{P}$ application (NP) and with $\mathrm{P}$ (WP) supplied.

\begin{tabular}{llcc}
\hline & \multirow{2}{*}{ Cultivar } & \multicolumn{1}{c}{ Number of tillers per plant } \\
\cline { 2 - 4 } & \multicolumn{1}{c}{$\mathrm{NP}$} & WP & Mean \\
\hline RB92-579 & $0.25 \mathrm{Bb}$ & $4.75 \mathrm{Aa}$ & 2.50 \\
RB85-5156 & $0.00 \mathrm{Bb}$ & $2.25 \mathrm{Ba}$ & 1.13 \\
RB86-7515 & $0.00 \mathrm{Bb}$ & $2.25 \mathrm{Ba}$ & 1.13 \\
RB96-6928 & $3.75 \mathrm{Aa}$ & $3.75 \mathrm{Aba}$ & 3.75 \\
\hline Mean & 1.00 & 3.25 & \\
\hline
\end{tabular}

Different capital letters within the same column show significant differences between cultivars by LSD test ( $p \leq 0.05)$. Different small letters within the same row shows significant difference between NP and WP by LSD test $(p \leq 0.05)$. ${ }^{\text {ns }}$ Not significant by LSD test $(p>0.05)$ 
Shoot dry matter accumulation was increased significantly ( $p \leq 0.05$ ) by $\mathrm{P}$ application across all four cultivars (Figure 2A). Under low available P (NP), cultivar RB96-6928 showed the highest shoot and root dry matter, and also, this cultivar produced significantly more roots than all other cultivars considering total length, root diameter and root mass fraction (Table 1).
All cultivars responded significantly to $\mathrm{P}$ application (Figure 2A) with highest shoot DM being observed for cultivar RB92-579 under high P (WP). Cultivar RB96-6928 had the highest root DM at high P (WP) compared to the other cultivars, whereas cultivar RB86-7515 showed poor shoot and root development at both levels of $\mathrm{P}$.

A)

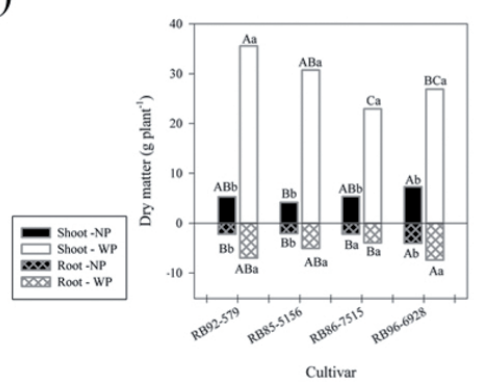

B)

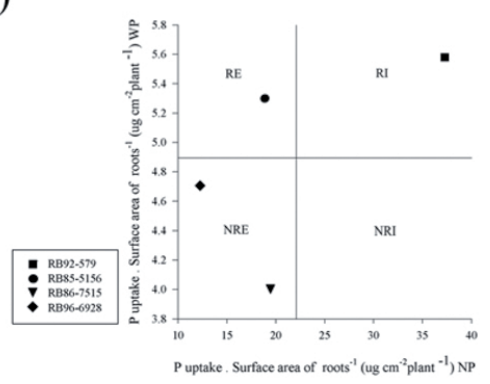

C)

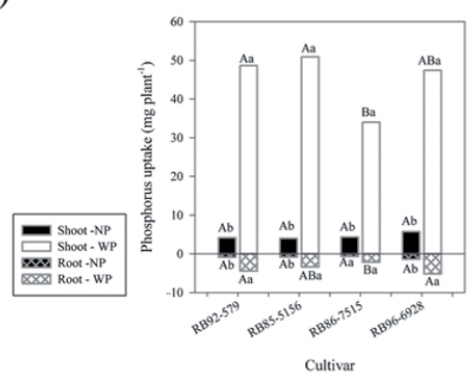

Figure 2.A) Shoot and root dry matter B) Classification of sugarcane cultivars based on P uptake per unit of root surface area showing responsive efficient (RE), responsive inefficient (RI), Non-responsive efficient (NRE), and Non-responsive inefficient (NRI) for four cultivars grown without P application (NP) and with P (WP). C) P uptake in shoot and root of sugarcane at 45 days after transplanting for four cultivars grown without $\mathrm{P}$ application (NP) and with P (WP) supplied. Different capital letters show significant differences between cultivars by Duncan test $(p<0.05)$. Different small letters show significant difference between NP and WP by LSD test $(p<0.05)$. 
The efficiency of the sugarcane cultivars for P uptake was determined by assessing plant $\mathrm{P}$ uptake in relation to total root surface area (Figure 2B). The amount of $\mathrm{P}$ accumulated in shoot and root (P uptake) was higher for cultivar RB96-6928, both under NP and WP conditions (Figure 2C), which is consistent with the observed differences in shoot DM. However, under high P the cultivars RB92-579 and RB96-6928 contained more P stored in the root system than RB86-7515. For shoot $\mathrm{P}$ accumulation, cultivars RB92-579 and RB855156 had the highest P content, RB96-6928 was intermediate and RB86-7515 contained significantly less total P. As a consequence, the P-uptake efficiency of the cultivars varied, with cultivar RB92-579 showing the highest $\mathrm{P}$ uptake per unit root at both NP and WP (Figure 2B). By contrast, cultivar RB92-579 was both efficient at low $\mathrm{P}$ and more responsive for $\mathrm{P}$ uptake with applied fertilizer. Interestingly, the larger root system for cultivar RB96-6928 did not confer greater $\mathrm{P}$ uptake per unit of root making this cultivar relatively inefficient at NP and unresponsive to high P (WP).

\subsection{Response of RB96-6928 cultivar to P levels and rhizosphere interactions}

Based on the significantly larger root system observed for cultivar RB96-6928 at low P and its capacity to maintain tillering and shoot growth at this condition, this cultivar was further assessed for growth and rhizosphere interactions across a wider range of $\mathrm{P}$ levels.

Changes in rhizosphere properties were analyzed at various distances from the root surface as shown in Figure 3. Lowest soil $\mathrm{pH}$ was observed in soil without $\mathrm{P}$ addition (control), with soil $\mathrm{pH}$ being similar across all sections up to $\sim 9 \mathrm{~mm}$ from the root surface. When $\mathrm{P}$ was applied, soil $\mathrm{pH}$ was higher $(\mathrm{p}<0.05)$ compared to control (Figure $3 \mathrm{~A}) . \mathrm{AP}_{\mathrm{ASE}}$ in the rhizosphere similarly varied in response to $\mathrm{P}$ fertilization, with highest activity across all sections in soils under lower $\mathrm{P}$ availability (Figure 3B). Microbial biomass $\left(\mathrm{P}_{\text {MIC }}\right.$ ) was similarly affected by $\mathrm{P}$ rate, but only significant different across $\mathrm{P}$ treatments near to the rhizoplane $(p<0.05)$, where lowest $\mathrm{P}_{\text {MIC }}$ was observed in the absence of applied $\mathrm{P}$ or at the lowest $\mathrm{P}$ level.

No differences in $\mathrm{P}_{\mathrm{MIC}}$ occurred beyond $3 \mathrm{~mm}$ from the root surface and at this distance $\mathrm{P}_{\mathrm{MIC}}$ was not different from the bulk soil (Figure 3C).

Resin extractable labile $\mathrm{P}\left(\mathrm{P}_{\mathrm{AER}}\right)$ was similar across all rhizosphere sections, and was significantly increased only with higher rates of $\mathrm{P}$ application (Figure 3D). 
A)

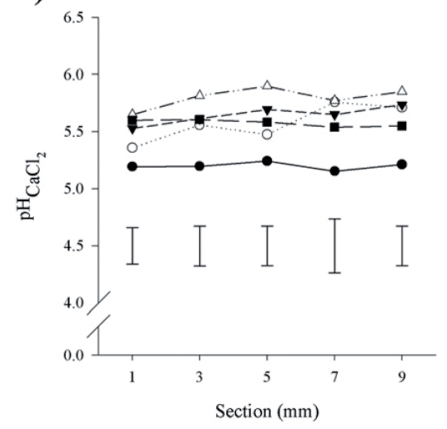

C)

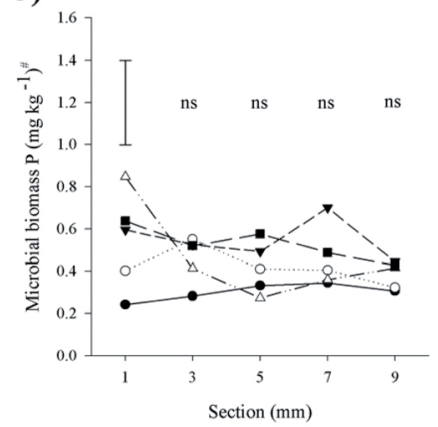

В)

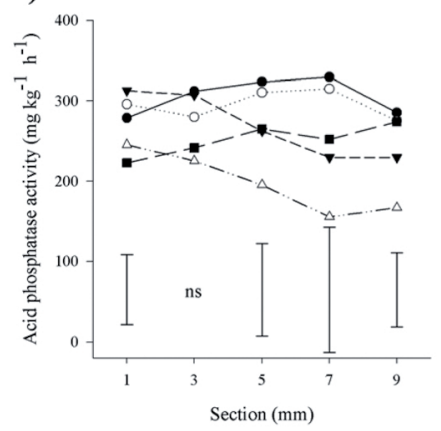

D)

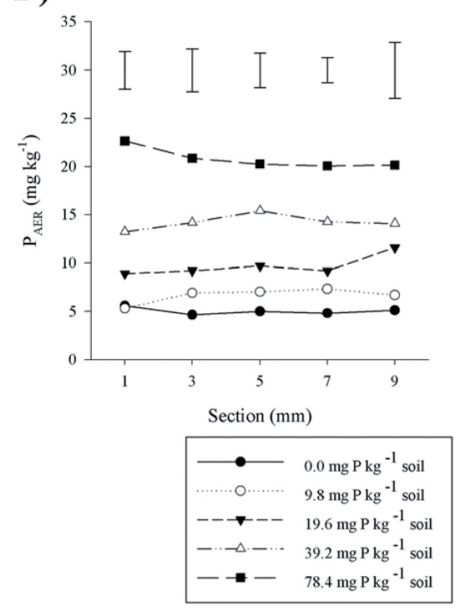

Figure 3. A) Soil $\mathrm{pH}, \mathrm{B})$ acid phosphatase activity $\left(\mathrm{AP}_{\mathrm{ASE}}\right)$, C) microbial biomass and $\left.\mathrm{D}\right) \mathrm{P}$ extracted by anion exchange resin $\left(\mathrm{P}_{\mathrm{AER}}\right)$ across soil sections in response to $\mathrm{P}$ application rate for sugarcane seedlings for cultivar RB96-6928. Error bars denote mean square error. ${ }^{\mathrm{ns}}$ not significant by $\mathrm{F}$ test $(p>0.05)$

When grown across a range of $\mathrm{P}$ supplies, cultivar RB96-6928 showed a significant response to $\mathrm{P}$ $(p \leq 0.05)$ for shoot DM, P uptake and mycorrhizal colonization (Figure 4). The quadratic regression $\left(\mathrm{R}^{2}=0.96\right)$ indicated that $90 \%$ of maximum shoot DM (12.1 g plant $^{-1}$ ) was achieved with $\mathrm{P}$ application at level of $38.5 \mathrm{mg} \mathrm{P} \mathrm{kg}^{-1}$ (Figure 4A). The $\mathrm{P}$ uptake by plants increased linearly with $\mathrm{P}$ application (Figure 4B) and at the critical rate of P supply (38.5 mg $\mathrm{P} \mathrm{kg}^{-1}$ ), plants produced $24 \mathrm{mg} \mathrm{kg}^{-1}$ of shoot DM, resulting in a critical internal $\mathrm{P}$ concentration of $0.198 \%$ (1.98 $\mathrm{mg} \mathrm{P} \mathrm{g}^{-1} \mathrm{DM}$ ) for $90 \%$ maximum growth. Mycorrhizal colonization (MC) by AMF was negatively affected by increasing $\mathrm{P}$ rates, with $38 \%$ of roots colonized in the control without $\mathrm{P}$ application and only $18 \%$ in soils under higher rates of $\mathrm{P}$ application (70 $\mathrm{mg} \mathrm{P} \mathrm{kg}^{-1}$ ) (Figure 4C). At the critical level of P supply (38.5 mg $\mathrm{P} \mathrm{kg}^{-1}$ ), the plants showed approximately $22.5 \%$ colonization. 

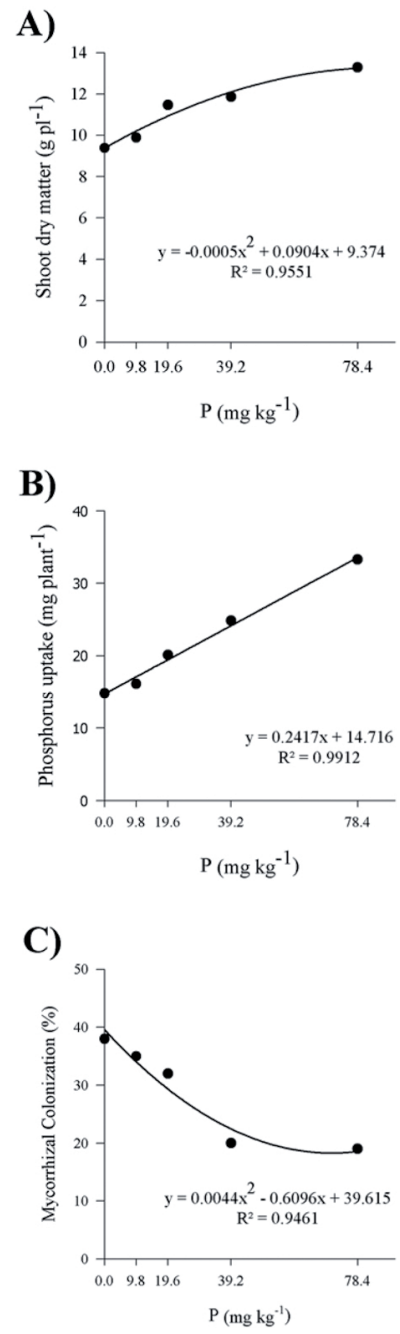

Figure 4. A) Shoot dry matter; B) Total phosphorus uptake; and C) Mycorrhizal colonization (MC) of sugarcane seedling under five rates of $\mathrm{P}_{2} \mathrm{O}_{5}$. ${ }^{*}$ significant by LSD test $(p \leq 0.05)$. ${ }^{\text {ns }}$ Not significant by LSD test $(p>0.05)$. \#Transformed data to arc sen $\sqrt{\mathrm{P}} \%$ / 100 , where $\mathrm{P}$ is the percentage of assessed mycorrhizal colonizatio

\section{Discussion}

The nutrition of grass with $\mathrm{P}$ is known to define the plantation yield, which has been suggested to be associated with plant development and tillering in sugarcane (Dillewijn, 1952, El-Tilib et al., 2004), wheat
(Fioreze et al., 2012) and rice (Yoshida, 1981). In support of our hypothesis that the four sugarcane cultivars examined displayed differing plant and root morphologies, in our study, cultivars RB85-5156 and RB86-7515 showed high dependency on $\mathrm{P}$ availability for both biomass accumulation and tillering. 
Cultivar RB96-6928 presented higher number of tillers both under NP and WP, suggesting an ability to adapt under - low soil P conditions. The higher root mass fraction can exhibit more susceptibility to $\mathrm{P}$ deficiency (Machado and Furlani, 2004). Although RB96-6928 had the highest root mass fraction but it produced more tillers under NP and can challenge this hypothesis in sugarcane cultivars, exhibiting a larger root system with higher root length and hence greater root volume, improving root biomass under both NP and WP. Association between production efficiency under low $\mathrm{P}$ conditions and development of large root systems has been suggested, and in our study a larger root system and maintenance of growth at low $\mathrm{P}$ by RB96-6928 increased P uptake efficiency, which is considered to be an important mechanism for roots to adapt to nutritional stresses (Tariq Aziz et al., 2005). This may be important for $\mathrm{P}$ acquisition from soil given that $\mathrm{P}$ mobility in soil is low and $\mathrm{P}$ moves from soil to root surfaces lowly by diffusion. Increased total absorptive surface in roots may therefore enhance the capacity of sugarcane root to explore soil $\mathrm{P}$ more effectively. Changes in root architecture are an adaptive measurement to increase the absorptive surface of the root system (López-Bucio et al., 2003).

Regarding to soil, $\mathrm{P}$ availability has changed the rhizosphere and impacted the microbial properties. The labile $\mathrm{P}$ content in the soil was not affected across the four cultivars, being only affected by $\mathrm{P}$ application. Perhaps the short duration of this study (45 days) can explain the lack of fertilizer effect to equilibrate with the soil in terms of inorganic labile $\mathrm{P}$ for plant growth in the rhizosphere. However, fertilizer addition clear had an effect, suggesting that $\mathrm{P}$ taken up may be continuously replaced (in the rhizosphere). Difference in soil $\mathrm{P}$ contents leads to a major shift in bacterial community structure, which is consistent with other studies because the presence of fertilizer has altered the microbial community composition compared to no fertilizer. In addition, changes in the rhizosphere can be provided directly by the microorganisms present in the soil. In our approach, no differences were observed among cultivars. In this case, if distinct bacterial groups are selected to supply P to plants, they may either be commonly present across all cultivars or be represented in low frequency that did enable effective differentiation (Andreote et al., 2009). Indeed, the separation between soils amended or not with $\mathrm{P}$ shows the role of soil fertilization upon microbial assemblages in the rhizosphere and also in the richness. The low number of species under absence of available $P$ results in reduction of the interaction between microorganisms and plant. On the other hand, under high $\mathrm{P}$, indicated more richness for all sugarcane cultivars, showing that the presence of phosphate provided adequate environmental conditions for the development of a larger number of species that interact to each other and increase plant development. However, the difference in mycorrhizal colonization in different $\mathrm{P}$ availability condition is likely to be important. It is suggesting that there is 'microbial' shift, based on percentage of colonization, which is likely to indicate an important functional change to $P$ nutrition.

The cultivars are different from each other in genetic backgrounds, what would enable plants to utilize different strategies to acquire $P$ from soil through variation in root system structure and associated rhizosphere processes. Regardless of production, the four sugarcane cultivars assessed in this study exhibited varied growth potential and showed difference in responsiveness to $\mathrm{P}$ application and efficiency in $\mathrm{P}$ use. If the cultivars were classified with respect to $P$ uptake as an isolated variable, cultivars RB85-5156, RB92-579 and RB96-6928 were classified as responsive and efficient and the cultivar RB86-7515 as being nonresponsive and efficient. However, here, the intended factor was P uptake by total surface area of root and indicated that cultivar RB85-5156 was the 
most responsive, whereas cultivars RB86-7515 and RB96-6928 were classified as nonresponsive and efficient. Selection of cultivars adapted to low P conditions might potentially target cultivars that are nonresponsive and thus are likely to be less dependent on $\mathrm{P}$ application. Cultivar RB86-7515 also exhibited lower plant height, reduced number of tillers per plant and had low volume of roots, resulting in low root and shoot dry matter and $\mathrm{P}$ uptake compared to cultivar RB96-6928.

The least $\mathrm{AP}_{\mathrm{ASE}}$ in RB96-6928 shows that among three plant strategies introduced by (Richardson and Simpson, 2011), this cultivar overcome P-starvation by root-foraging. On the other hand, these plants compensate low exudation of this enzyme by the development of a larger root system which allows more efficient uptake of $\mathrm{P}$ by the roots. This cultivar was classified as nonresponsive and efficient cultivar to plant P uptake per unit of surface area of root. RB96-6928 thus is an efficient cultivar in terms of P uptake (Da Silveira et al., 2014) reported similar results across 23 sugarcane cultivars under low or high $\mathrm{P}$ conditions. Based on these features, RB96-6928 is a good cultivar for low $\mathrm{P}$ conditions and more detailed and fine scale sampling of the rhizosphere of RB96-6928 is justified. The results of RB96-6928 showed that the changes in the rhizosphere under low $\mathrm{P}$ availability were associated with decreased soil $\mathrm{pH}$, which could be driven by direct acidification of the rhizosphere or release of organic acids (Zhang et al., 1997), in response to $\mathrm{P}$ stress by the plant. In our approach $\mathrm{P}_{\text {MIC }}$ did not show effect across treatments with either cultivar or P level. However, across the rhizosphere sections, the roots were affected by $\mathrm{P}_{\text {MIC }}$, where just near to the root surface lower $\mathrm{P}_{\text {MIC }}$ was observed. These differences may be indicative of intense competition for available $\mathrm{P}$ between roots and microorganism that is particularly evident under higher P stress. Increase in microbial biomass within the rhizosphere may also increase acid phosphatase activity, although the origin of such activity from either microorganisms or plant roots remains unclear. Many activities of microorganisms are regulated by the plant through the rhizosphere, as observed for the increased $\mathrm{P}_{\text {ASE }}$ (Gianfreda, 2015), only produced by microbial cells (Sato et al., 2015).

Considering the plant production, based on the $90 \%$ of the maximum shoot dry matter, the rate of $P$ supply required for optimal growth for cultivar RB96-6928 was determined at $38.5 \mathrm{mg} \mathrm{P} \mathrm{kg}^{-1}$ soil which provided sufficient $\mathrm{P}$ uptake to attain a critical internal $\mathrm{P}$ concentration to support maximum plant growth. Decreased mycorrhizal colonization with increasing P supply proves a lesser dependence of plant on mycorrhizas at higher $P$ availability., similarly, reported a higher colonization of sugarcane by endophytic plant-growth-promoting bacteria under low $\mathrm{P}$ availability.

\section{Conclusions}

In general, the results support our suggestion that plants may adapt to P deficiency by either the modification of their root structure, such as development of more root biomass, or the establishment of interactions with microorganisms in the roots vicinity. The rate of $\mathrm{P}$ supply required for optimal growth for cultivar RB96-6928 was up to $38.5 \mathrm{mg} \mathrm{P} \mathrm{kg}^{-1}$ soil, which provided sufficient $\mathrm{P}$ uptake to attain a critical internal $\mathrm{P}$ concentration to support maximum plant growth.

Collectively, our results indicate that P efficiency in sugarcane was predominantly associated with the generation of high root biomass and surface area.

\section{Acknowledgements}

We thanks for the support of this project by Sao Paulo Research Foundation (FAPESP) grant \#2013/21604-1 and a master's scholarship \#2013/23575-9. 


\section{References}

Andreote, F. D., Azevedo, J. L., Araújo, W.L. 2009. Assessing the diversity of bacterial communities associated with plants. Braz. J. Microbiol. 40, 417-432.

Brookes, P. C., Landman, A., Pruden, G., Jenkinson, D. S. 1985. Chloroform fumigation and the release of soil-nitrogen - a rapid direct extraction method to measure microbial biomass nitrogen in soil. Soil Biol Biochem. 17, 837-842.

Companhia Nacional de Abastecimento - CONAB. 2015. Acompanhamento da safra brasileira de cana-de-açúcar. quarto levantamento - safra 2014/15. http.//www.conab.gov.br/OlalaCMS/ uploads/arquivos/15_04_13_08_45_51_boletim cana_portugues_-_4o_lev_-_14-15.pdf (August, 2016).

da Silveira, G. C. de A, Paulo, M., Kist, V., Almeida, C. de F., Baffa D. C. F., Barbosa, M. H. P. 2014. Genetic Variation Affecting Agronomic Traits in Sugarcane in Response to High and Low Phosphorus Availability. Agron J. 106, 2296-2304.

Dillewijn, C. V. 1952. Botany of sugarcane. Chronica Botanica, Walthham, $371 \mathrm{p}$.

El-Tilib, M., Elnasikh, M., Elamin, E. 2004. Phosphorus and potassium fertilization effects on growth attributes and yield of two sugarcane varieties grown on three soil series. J Plant nutr. 27, 663699.

FAO. Food and agricultural commodities production. 2015: Country rank in the world, by commodity. http.//faostat.fao.org/site/339/default.aspx (August, 2016).

Fioreze, S.L., Castoldi, G., Pivetta, L.A., Pivetta, L.G., Fernandes, D.M., Büll, L.T. 2012. Tillering of two wheat genotypes as affected by phosphorus levels. Acta Sci. Agron. 34, 331-338
Gahoonia, T. S., Nielsen, N. E. 1991. A method to study rhizosphere processes in thin soil layers of different proximity to roots. Plant Soil. 135, 143-146.

Gianfreda, L. 2015. Enzymes of importance to rhizosphere processes. J. Soil Sci and Plant Nutr. 15, 283-306.

Giovannetti, M., Mosse, B. 1980. Evaluation of techniques for measuring vesicular arbuscular mycorrhizal infection in roots. New Phytol. 84, 489-500.

Hammer, O., Harper, D., Ryan, P. 2001. PAST - Palaeontological statistics software package for education and data analysis. Paleontological Electronica, Boulder, 9 p.

Hedley, M. J., Stewart, J., Chauhan, B. 1982. Changes in inorganic and organic soil phosphorus fractions induced by cultivation practices and by laboratory incubations. Soil Sci Soc Am J. 46, 970-976.

Heuer, H., Krsek, M., Baker P, Smalla, K., Wellington, E. 1997. Analysis of actinomycete communities by specific amplification of genes encoding 16S rRNA and gel-electrophoretic separation in denaturing gradients. Appl Environ Microb. 63, 3233-3241.

Khan, M. S., Zaidi, A., Ahemad, M., Oves, M., Wani, P.A. 2010. Plant growth promotion by phosphate solubilizing fungi-current perspective. Arch AckerPfl Boden. 56, 73-98.

Larsen. J., Jaramillo-López, P., Nájera-Rincon, M., González-Esquivel., C. 2015: Biotic interactions in the rhizosphere in relation to plant and soil nutrient dynamics. J. Soil Sci and Plant Nutr. 15, 449-463.

López-Bucio, J., Cruz-Ramírez, A., Herrera-Estrella, L. 2003. The role of nutrient availability in regulating root architecture. Curr Opin Plant Biol. 6, 280-287.

Machado, C. T. d T., Furlani, Â. M. C. 2004. Kinetics of phosphorus uptake and root morphology of 
local and improved varieties of maize. Sci Agric. 61, 69-76.

Malavolta, E., Vitti, G. C., Oliveira, S. A. 1997. Avaliação do estado nutricional das plantas. princípios e aplicações. Potafos, Piracicaba, 319 p.

McCaig, A. E. Glover, L. A., Prosser, J. I. 2001. Numerical analysis of grassland bacterial community structure under different land management regimens by using $16 \mathrm{~S}$ ribosomal DNA sequence data and denaturing gradient gel electrophoresis banding patterns. Appl Environ Microb. 67, 45544559.

Murphy, J., Riley, J. P. 1962. A modified single solution method for determination of phosphate in natural waters. Ann Chim Acta. 26, 31-36.

Pinton, R., Varanini, Z., Nannipieri, P. 2001. The rhizosphere as a site of biochemical interactions among soil components, plants, and microorganisms. Basel, New York, 424 p.

Raghothama, K.G., Karthikeyan, A.S. 2005. Phosphate acquisition. Plant Soil. 274, 37-49.

Raij, B. V., Cantarella, H., Quaggio, J., Furlani, A. 1997. Recomendações de adubação e calagem para o Estado de São Paulo. Instituto Agronômico; Fundação IAC, Campinas, 285 p.

Richardson, A. E. Simpson, R. J. 2011. Soil microorganisms mediating phosphorus availability update on microbial phosphorus. Plant Physiol. 156, 989-996.
Sato, T., Ezawa, T., Cheng, W., Tawaraya, K., 2015. Release of acid phosphatase from extraradical hyphae of arbuscular mycorrhizal fungus Rhizophagus clarus. Soil Sci Plant Nutr. 61, 269-274.

Shen, J., Yuan, L., Zhang, J., Bai, H., Li, Z., Chen, X., Zhang, W., Zhang, F. 2011. Phosphorus dynamics. from soil to plant. Plant Physiol. 156, 997-1005.

Tabatabai, M. 1994. Soil enzymes. Methods of soil analysis, 2, 775-833.

Tariq Aziz, P., Maqsood, M. A., Mansoor, T. 2005. Differences in phosphorus absorption, transport and utilization by twenty rice (Oryza sativa 1.) cultivars. Pak. J. Agri. Sci. 42, 3-4.

Vance, E. D., Brookes, P. C., Jenkinson, D. S. 1987. An extraction method for measuring soil microbial biomass-c. Soil Bio Biochem. 19, 703-707.

Vierheilig, H., Coughlan, A. P., Wyss, U., Piché, Y. 1998. Ink and vinegar, a simple staining technique for arbuscular-mycorrhizal fungi. Appl Environ Microb. 64, 5004-5007.

Yoshida, S. 1981: Fundamentals of rice crop science, Int. Rice Res. Inst., Los Baños, 269p.

Zhang, F., Ma, J., Cao, Y. 1997. Phosphorus deficiency enhances root exudation of low-molecular weight organic acids and utilization of sparingly soluble inorganic phosphates by radish (Raghanus satiuvs L.) and rape (Brassica napus L.) plants. Plant Soil. 196, 261-264. 